\title{
Effect of Low Level Laser Therapy on Gingival Inflammation in Patients undergoing Fixed Orthodontic Treatment: A Randomized Clinical Trial
}

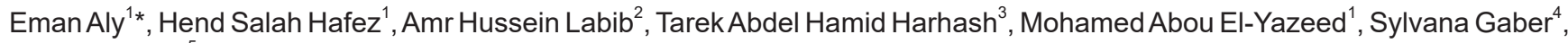
Shaimaa $\mathrm{Nasr}^{5}$

${ }^{1}$ Department of Orthodontics and Pediatric Dentistry, National Research Centre, Cairo, Egypt; ${ }^{2}$ Department of Orthodontics, Faculty of Oral and Dental Medicine, Cairo University, Egypt; ${ }^{3}$ Department of Dentistry, National Institute for Laser Enhanced Sciences, Cairo University, Egypt; ${ }^{4}$ Department of Medical Microbiology and Immunology, Faculty of Medicine, Fayoum University, Egypt; ${ }^{5}$ Department of Periodontology, Faculty of Oral and Dental Medicine, Fayoum University, Egypt

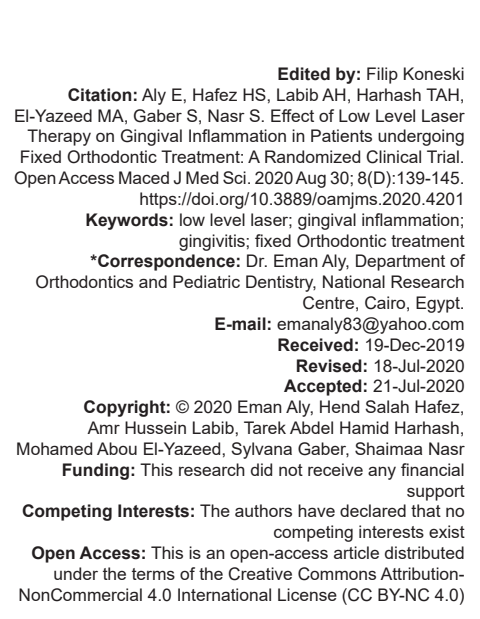

Abstract

AIM: The aim of this study was to compare the effect of low level laser therapy (LLLT) with non-LLLT as an adjunct to mechanical debridement in patients who develop gingival inflammation during fixed orthodontic treatment.

MATERIALS AND METHODS: Thirty subjects undergoing comprehensive fixed orthodontic treatment were randomly allocated. Split mouth design was applied for each patient, where the four quadrants were randomly allocated to receive full mouth debridement. The test group (quadrant) received three laser sessions (days 1,3 , and 5 ) besides debridement while the control group (quadrant) received debridement only. Both bleeding index (BI) and plaque index (PI) were measured after 1 and 3 months, while the total colony forming units (CFU) were measured after 2 and 6 weeks.

RESULTS: Clinical assessments (BI and PI) showed a statistically significant decrease at the first follow-up (after 1 month) and a slight increase in the second (after 3 months) that did not reach the base line. While, the total CFU showed a significant decrease in both follow-ups.

CONCLUSION: Laser showed superior results in the treatment of gingival inflammation induced by fixed orthodontic appliances other than debridement only.

\section{Introduction}

Oral hygiene is an important determinant of orthodontic treatment. It is well established that poor oral hygiene affects orthodontic treatment outcomes and influences the quality of the treatment, leading to a prolonged treatment time due to the accumulation of supra- and subgingival plaque. In addition, it results in the establishment of a pro-inflammatory state leading to gingivitis and gingival hyperplasia, which also causes patient discomfort [1], [2].

Orthodontic patients with fixed appliances face a challenge in maintaining proper oral hygiene as well as good periodontal health, especially younger patients [3]. Any orthodontic treatment represents a serious invasion to the oral environment since the numerous orthodontic components impede the maintenance of oral hygiene [4]. Fixed orthodontic appliances facilitate the accumulation of plaque and the development of biofilm, inducing dysbiosis, which is an imbalance between the types of organisms present in the oral natural microflora. The accumulation of plaque on brackets and the resins used to bond them lead to a shift in the balance of the normally stable resident oral microbiome worsening the periodontal conditions. This shift can be observed whether clinically or by immunohistochemical examination [5]. However, orthodontic treatment may lead to a potential irreversible periodontal alteration at the cellular level due to pathological inflammation [6].

It was observed that the plaque configuration seen on bracket recesses differs in its biological and chemical parameters from that seen on regular plaque [7]. In addition to a reduced $\mathrm{pH}$ and increased amounts of calcium, phosphate, and carbohydrates, the plaque is characterized by larger numbers of bacterial counts leading to the development of gingivitis [8], [9], [10]. Several studies showed that even 
patients with good oral hygiene who are treated with fixed orthodontic appliances may develop gingivitis [11], [12]. Bacterial metabolic products were able to penetrate the epithelium and disturb its functional and structural integrity [13], [14].

For any orthodontist, such conditions are very challenging. They impede the orthodontic treatment due to excessive bleeding and inaccessibility to the brackets due to gingival hyperplasia. In persistent gingivitis as well as in cases developing active periodontitis, orthodontic treatment is stopped and orthodontic wires are removed until the inflammation is controlled. In some patients with persistent hyperplasia, gingivectomy is indicated to continue the treatment.

The golden standard of treating gingival inflammation is sub-gingival and supra-gingival debridement whether using manual instruments or ultrasonics. Lately, soft laser was used in soft tissue curettage and sulcular debridement [15].

Diode laser is a soft tissue laser of $810 \mathrm{~nm}$ or 910-980 nm wavelength. It has some beneficial effects such as the acceleration of wound healing, promotion of angiogenesis, and augmentation of growth factor release [16]. Low level laser has an effective bactericidal effect without dental hard tissues interaction. Part of the laser energy scatters and penetrates into periodontal pockets during irradiation. This leads to stimulation of the cells of surrounding tissues and results in the reduction of the inflammatory conditions as well as an increase in cell proliferation and the lymph flow causing an improvement in the periodontal tissue attachment and as well as a marked reduction in post-operative pain besides the bactericidal effect [17], [18], [19].

The aim of this study was to examine whether low level laser therapy (LLLT) compared to no laser therapy decrease gingival inflammation in patients who develop gingival inflammation during fixed orthodontic treatment.

\section{Materials and Methods}

Thirty subjects undergoing comprehensive fixed orthodontic treatment were selected from the outpatient clinic of the Orthodontic Department, Cairo University, Egypt. A double-blind, split mouth, and randomized controlled trial were conducted, where four quadrants in each patient for a total of 120 quadrants, were randomly allocated to receive low-level laser or no laser treatments.

IRB approval was granted and subjects and guardians, who agreed to join the study, and signed an informed consent explaining the trial aim, procedure, and possible side effects. Central random sequence generation, for 30 subjects was performed, in the
RANDOM.ORG software by the trial coordinator who was responsible for allocation concealment, and did not identify the allocation of each quadrant to the operator till after the patients' personal information was recorded and was not further involved in the trial.

The subjects included in the study met the following criteria:

- $\quad$ Orthodontic patients treated with fixed orthodontic appliances for at least 6 months having gingivitis.

- Females (to exclude hormonal changes in females than males as a factor) [20].

- $\quad$ Age range 15-25.

- No apparent systemic disease.

Full-mouth clinical examination was carried out for each patient before treatment, to assess bleeding index $(\mathrm{BI})$, plaque index $(\mathrm{PI})$, pocket probing depth, and clinical attachment level (CAL). Gingivitis was reported when there was bleeding on probing and pocket depth $<4 \mathrm{~mm}$ showing no attachments loss [21].

Bacterial count, that is, the total number of colony forming unit (CFU)/ml, was also measured. The pre-operative assessment of each quadrant was performed using periodontal screening recorded with online periodontal chart (periodontalchart-online.com), to assess the bleeding on probing index and PI. Postoperative assessment was performed for the same parameters after 4 weeks and 3 months follow-up period [22], [22]. [23].

Patients were masked to the type of treatment that was applied to each side, where the laser applicator was applied to the control side in a manner similar to the test side without activating the laser unit. Moreover, the operators and the outcome assessors were blinded to the treatment allocation during the study.

A total of 120 samples of gingival crevicular fluid were collected before treatment and after 2 weeks and 6 weeks of treatment using sterile paper points that were inserted into the gingival crevice and kept in place for $20 \mathrm{~s}$. The paper points were pooled in screw-cap vial containing the transferring media (Thioglycollate broth media), and transferred within 30 min to the Department of Microbiology and Immunology, Faculty of Medicine, Cairo University, Egypt, for microbiological analysis. The samples were aerobically and anaerobically cultured on non- selective blood agar and MacConkey media (Oxoid LTD, Basingstoke, England) for aerobic bacteria and also on selective anaerobic media (Brucella blood agar), (Wilkins Chalgren Anaerobic Agar Base media) (HiMedia) in Gaspack anaerobicjar (HiMedia)for anaerobic bacteria. The inoculated Brucella blood agar and Wilkins Chalgren Anaerobic Agar Base media plates were anaerobically incubated at $37^{\circ} \mathrm{C}$ for $4-7$ days. While, blood agar and MacConkey media were aerobically incubated at $37^{\circ} \mathrm{C}$ for 2 days. Selective anaerobic media plates were used to demonstrate black-pigmented Bacteroides species (spp.), Actinobacillus actinomycetemcomitans, Eikenella 
corrodens, Fusobacterium and Capnocytophaga spp., and other periodontal bacteria such as Porphyromonas gingivalis and Prevotella intermedia [24], [25].

Colonies were identified by standard microbiological conventional methods [26] and according to methods described by Slots [24]. Standard microbiological conventional methods include gram staining, shape, size, spore formation, and motility. Isolates were enumerated. Total viable counts were defined as the total number of CFU/ml. Aerobic Gram-positive colonies were isolated from blood agar and identified by microscopic examination, catalase test, coagulase test, and oxidase test for Gramnegative cocci. Any oxidase-negative Gram-negative rods were isolated from MacConkey agar and further identified by Microbact (12A) Gram-negative identification system (Oxoid, Basingstoke, UK).

AnaerobicAnaerobic colonies were isolated from selective media and identified by the following standard methods: the colony morphology, staining, and biochemical reactions [27]. Bacterial identification was completed by Viteck-2 automated identification system using ANC cards.

The laser device (Epic, Biolase) was used in the test quadrants with $940 \mathrm{~nm}$ wavelength and 0.5 Watt as power for 6 min total (30 s rest every 1 min application) with a total energy of $180 \mathrm{~J}$ in the $1^{\text {st }}, 3^{\text {rd }}$, and $5^{\text {th }}$ days.

Data for the $\mathrm{BI}, \mathrm{PI}$ and bacterial counts showed a non-normal distribution. The Friedman test was used to compare the change within each group overtime while the Mann-Whitney test compared the two groups at different time points. The confidence level was set at 95\%. Descriptive statistics were reported as medians and ranges.

\section{Results}

\section{Participant flow}

The study took place over 7 months from September 2018 to March 2019. Figure 1 explained that initially, 45 patients were recruited, but 15 did not comply. Ten of the 15 did not follow the inclusion criteria, and five did not have a will to complete These 15 patients were excluded from the study. The 30 participating patients went through the study, where four quadrants in each patient forming a total of 120 quadrants, were randomly allocated to receive lowlevel laser or no laser and debridement only. Of the 30 patients, there were four patients considered dropouts since they did not attend the follow-up appointments, making a final total of 26 subjects.

Table 1 showed that after 1 month as well as 3 months, the laser group showed statistically significantly lower $\mathrm{BI}$ and $\mathrm{PI}$ than the control group on

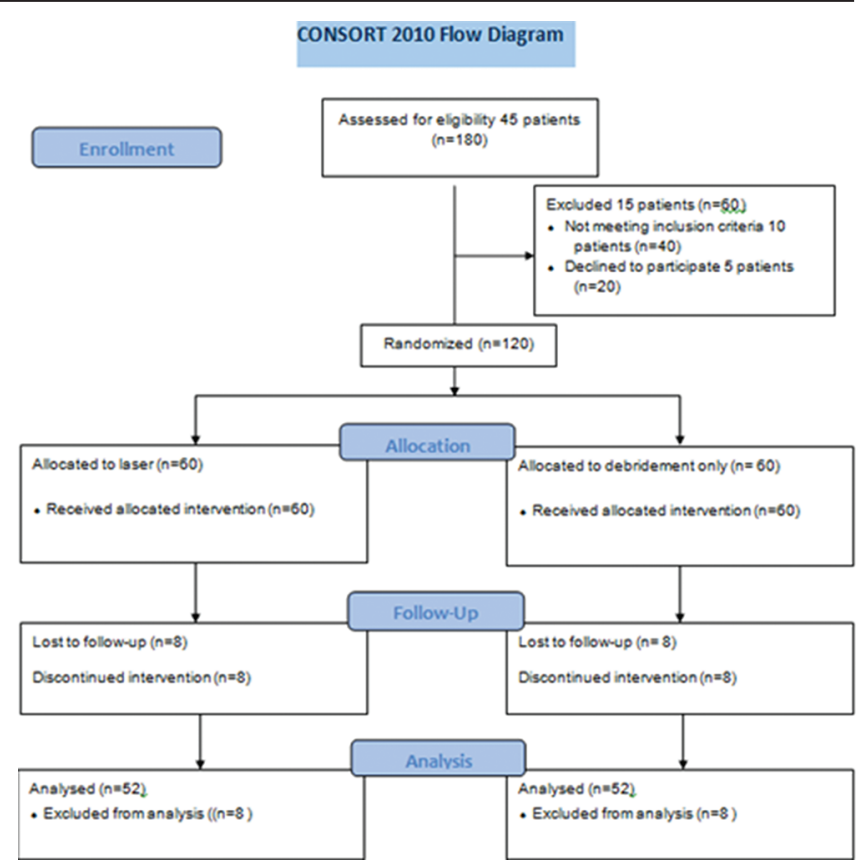

Figure 1: Consort flow diagram

comparing the $\mathrm{BI}$ between the two groups overtime. All three times were significantly different in both groups. Comparisons between the periods revealed that there was a statistically significant decrease after 1 month followed by a statistically significant increase in $\mathrm{BI}$ from 1 month to 3 months. However, the mean BI after 3 months still showed statistically significantly lower mean value compared to base line.

Furthermore, the results of the bacterial counts after 2 and 6 weeks showed statistically significant lower mean $\log _{10}$ CFU of the bacterial counts in the laser group compared to the control group. Furthermore, the comparisons between the periods revealed a statistically significant decrease in the mean $\log _{10}$ CFU of bacterial counts after 2 weeks as well as from 2 to 6 weeks. However, the mean $\log _{10}$ CFU of bacterial counts after 6 weeks showed statistically significantly lower mean value compared to base line.

Table 2 showed that there was a statistically significant direct correlation between $\mathrm{BI}$ and $\mathrm{PI}$, where the increase in $\mathrm{Pl}$ is associated with an increase in the $\mathrm{Bl}$ and vice versa. While, there was no statistically significant correlation between $\mathrm{BI}$ and bacterial counts or between $\mathrm{PI}$ and bacterial counts along time span.

\section{Discussion}

Main finding in the context of the existing evidence and interpretation

Orthodontic treatment represents serious invasion to the oral environment, as the orthodontic 
Table 1: $\mathrm{BI}, \mathrm{PI}$, and bacterial counts change in treatment and control group along time

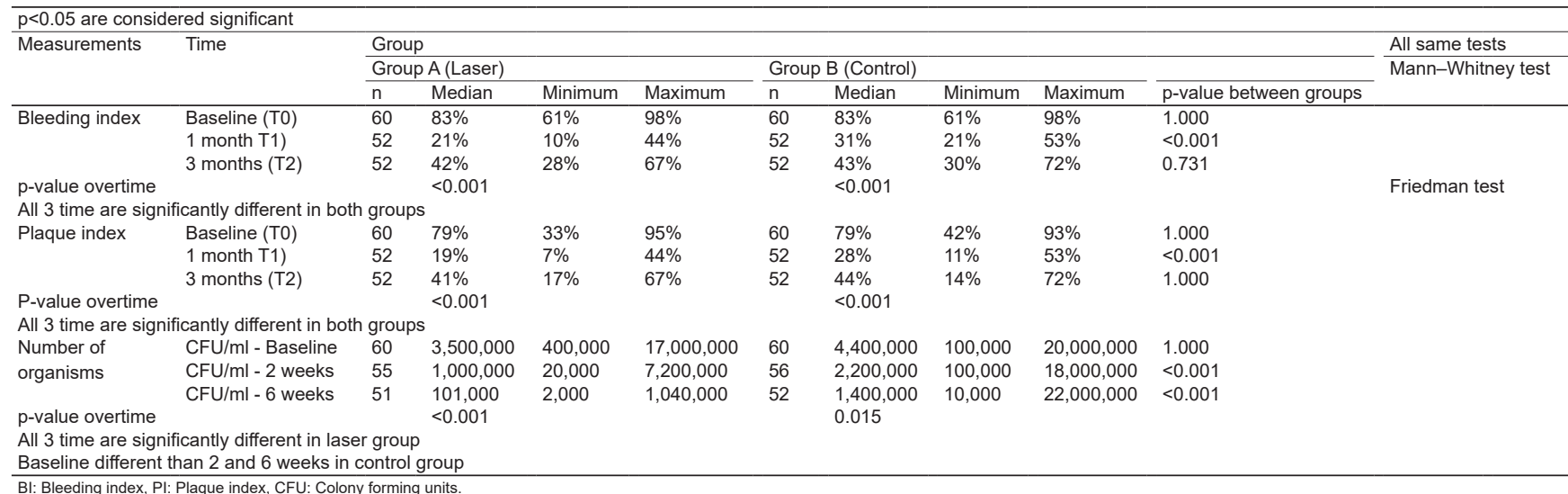

Table 2: Correlation between both groups and separate groups

\begin{tabular}{|c|c|c|c|c|c|c|c|c|c|}
\hline \multicolumn{10}{|c|}{$\begin{array}{l}\text { Both groups } \\
\text { Spearman's Rho correlations }\end{array}$} \\
\hline & & \multicolumn{2}{|c|}{ Bleeding index } & \multicolumn{2}{|c|}{ Plaque index } & & & & \\
\hline & & $\mathrm{r}$ & $\mathrm{p}$-value & $\mathrm{r}$ & $\mathrm{p}$-value & & & & \\
\hline \multirow[t]{2}{*}{ Baseline } & Plaque index & 0.481 & $<0.001$ & & & & & & \\
\hline & $\mathrm{CFU} / \mathrm{ml}$ & 0.116 & 0.207 & 0.073 & 0.428 & & & & \\
\hline \multirow[t]{2}{*}{2 weeks } & Plaque index & 0.562 & $<0.001$ & & & & & & \\
\hline & $\mathrm{CFU} / \mathrm{ml}$ & 0.366 & $<0.001$ & 0.444 & $<0.001$ & & & & \\
\hline \multirow[t]{2}{*}{6 weeks } & Plaque index & 0.603 & $<0.001$ & & & & & & \\
\hline & $\mathrm{CFU} / \mathrm{ml}$ & 0.243 & 0.015 & 0.329 & 0.001 & & & & \\
\hline \multicolumn{10}{|c|}{$\begin{array}{l}\text { Separate groups } \\
\text { Spearman's Rho correlations }\end{array}$} \\
\hline & & \multicolumn{8}{|c|}{ Groups } \\
\hline & & \multicolumn{4}{|c|}{ Group A (Laser) } & \multicolumn{4}{|c|}{ Group B (Control) } \\
\hline & & \multicolumn{2}{|c|}{ Bleeding index } & \multicolumn{2}{|c|}{ Plaque index } & \multicolumn{2}{|c|}{ Bleeding index } & \multicolumn{2}{|c|}{ Plaque index } \\
\hline & & $\mathrm{r}$ & $p$-value & $\mathrm{r}$ & $\mathrm{p}$-value & $r$ & $\mathrm{p}$-value & $\mathrm{r}$ & $p$-value \\
\hline \multirow[t]{2}{*}{ Baseline } & Plaque index & 0.473 & $<0.001$ & & & 0.481 & $<0.001$ & & \\
\hline & $\mathrm{CFU} / \mathrm{ml}$ & 0.031 & 0.816 & 0.009 & 0.945 & 0.193 & 0.139 & 0.142 & 0.279 \\
\hline \multirow[t]{2}{*}{2 weeks } & Plaque index & 0.221 & 0.116 & & & 0.142 & 0.315 & & \\
\hline & $\mathrm{CFU} / \mathrm{ml}$ & 0.082 & 0.566 & 0.393 & 0.004 & -0.002 & 0.989 & 0.197 & 0.162 \\
\hline \multirow[t]{2}{*}{6 weeks } & Plaque index & 0.681 & $<0.001$ & & & 0.495 & $<0.001$ & & \\
\hline & $\mathrm{CFU} / \mathrm{ml}$ & 0.215 & 0.137 & 0.305 & 0.033 & 0.310 & 0.029 & 0.457 & 0.001 \\
\hline
\end{tabular}

relationship; $>0.75$ (or -0.75$)=$ very good to excellent relationship. CFU: Colony forming units.

components impede the maintenance of good oral hygiene. This subsequently encourages the accumulation of dental plaque on brackets and allows coaggregation of pathogenic microorganisms, which may increase the risk of gingivitis and periodontitis [4].

Noteworthy, such conditions are very challenging for any orthodontist. These conditions hinder the orthodontic treatment sometimes due to excessive bleeding and gingival hyperplasia causing inaccessibility to the brackets. Moreover, in cases of persistent gingivitis, the situation may be deteriorated to develop periodontitis. This will force the orthodontist to stop orthodontic treatment due to CAL and bone resorption. This indicates that gingivitis should be managed early before developing periodontitis [2].

Management of gingivitis should target the etiological factors, mainly dental plaque which contains the bacterial bulk. Subsequently, signs of inflammation will be reduced leading to a significant improvement of gingival health. Therefore, the current study was conducted to assess the effect of diode laser on the subsidence of gingival inflammation that occurs in patients receiving orthodontic treatment.

Periodontal screening was performed before and after periodontal intervention to all patients to evaluate the degree of inflammation and gingivitis. Probing depth and CAL were measured and recorded using the online periodontal chart (Periodontalchartonline.com) to exclude cases with periodontitis and the bleeding and plaque indices were automatically calculated. The four quadrants of each patient were randomly allocated to receive either supra and subgingival debridement with diode laser or debridement only.

Results of the study showed improvement in the gingival condition of both groups after supragingival and subgingival debridement. That was evident by lower bleeding and plaque indices, as management of gingivitis is directly associated with a reduction in the oral biofilm [28]. However, more significant improvement in quadrants that received laser with debridement (test group) with statistically significant difference, where values of bleeding indices after 1 month and 3 months were reduced than those in the control group.

These results could be justified by the significant impact of diode laser on healing of the chronic inflammatory lesions in the sulcular epithelium (micro-ulcerations) that is responsible for bleeding in gingivitis [29]. This was in accordance to other studies, where it was proven that laser maintains coherence of 
tissues. In addition, it can gain the access to subgingival tissues and deeper layers through overlying tissue, enabling therapeutic penetration [30].

Moreover, the bacterial count in laser group was less than that in the control group. This could be due to its efficient bactericidal effect against pathogenic bacteria. These results were in agreement with Sasaki et al. as it was shown that viability of $P$. gingivalis was reduced after using Diode laser [31].

Some patients showed recurrent increase in plaque indices in both groups after 3 months, although they did not reach the pre-operative values. This could be explained due to another accumulation of plaque, especially in those with poor oral hygiene.

It was observed that low-level laser irradiation has an anti-inflammatory effect, a biostimulatory effect as well as an analgesic effect. The anti-inflammatory effect and edema reduction can partially be explained by a stronger circulation or stimulation immediately after laser therapy which increases the blood flow caused by low-level laser irradiation. This is not a heat effect, but the consequence of increased and normalized homeostasis in the tissue metabolism [32], [33], [34], [35]. Others have suggested that the anti-inflammatory effect may be the result of inhibition of mast cell degranulation [35]. Low-level laser irradiation is believed to stimulate or correct impaired cellular function [33].

Persistence of the anti-inflammatory effects of laser treatment can also have an impact on the decrease of plaque formation although the exact mechanism of inhibition of dental plaque caused by laser is not clear. Further experimental studies are needed to examine the effects of laser on vital cells in dental plaque. This may help explain the laser beam effects on gingival inflammation and the decrease in plaque bacteria.

In addition, regarding the anti-inflammatory effects of laser treatment on the inflamed gingiva, it should not be forgotten that laser irradiation, according to some authors, can reduce inflammation by directly affecting the oral biofilm bacteria. It has been previously shown that lipopolysaccharides from periodontal pathogenic bacteria can penetrate into gingival tissue and stimulate production of prostaglandin PgE2 [15], [36], [37].

In the present study, different aerobic (Streptococcus spp., Coagulase negative Staphylococcus, Staph aureus, Klebsiella pneumonia, Enterobacter cloacae, and Neisseria spp.) and anaerobic bacteria (Peptostreptcocci, P. gingivalis, Fusiform bacilli, Aggregatibacter actinomycetes, Prevotella melaninogenica, Bacteroides spp., and Bifidobacteria) were isolated from the cases. Kageyama et al. studied the relative abundance of subgingival plaque-specific bacteria in the in patients' microbiota, found that Streptococcus was the most predominant and that Prevotella, Veillonella, Fusobacterium, Leptotrichia, Porphyromonas, and Actinomyces were present in higher proportions in patients with gingivitis [38].
We found that the count of Fusobacterium species, $P$. melaninogenica, $A$. actinomycetes and $P$. gingivalis decreased after laser treatment compared with the control group. This is in agreement with Petrović et al., who evaluated microbiological and clinical efficacy of laser therapy for periodontal treatment [39]. These results were also in accordance with those observed by Birang et al. who detected the impact of adjunctive laser therapy and photodynamic therapy and observed significant reduction in microbial count of all treated groups compared to baseline $(p<0.5)$ [40]. In addition, Petrović et al. reported a significant decrease in the prevalence of bacteria after the treatment by laser. Gupta et al. evaluated the effectiveness of diode laser as an adjunct to scaling and root planning in the nonsurgical periodontal treatment. Moreover, they observed that the mean colony counts were equal in both groups at the baseline. However, the mean colony count was lower in the treated group as compared to the control group at all the subsequent time intervals [41].

Gupta et al. stated that the periodontal indices were higher and statistically significant in scaling and root planning alone group as compared to laser group on day 30, day 90, and day 180 [41]. Birang et al. found that the treated groups showed statistically significant improvements in CAL gain, periodontal pocket depth reduction, and papilla BI compared to baseline $(p<0.05)$.

\section{Limitations}

Relating the results of our study to other studies was difficult due to discrepancies in the results of clinical trials that have investigated the additional benefits of LLLT in non-surgical periodontal treatment. This is due to the presence of methodological differences such as reevaluation time points, microbiologicalassays, and laser parameters. The other studies that used low-level laser varied regarding the types of laser and the parameters of laser radiation [42], [43], [44], [45], [46], [47], but the clinical benefits observed when lasers are used are beyond doubt.

\section{Conclusion}

Laser showed superior results in the treatment of gingival inflammation induced by fixed orthodontic appliances other than debridement only.

\section{References}

1. Al-Jewair TS, Suri S, Tompson BD. Predictors of adolescent compliance with oral hygiene instructions during 
two-arch multibracket fixed orthodontic treatment. Angle Orthod. 2011;81(3):525-31. https://doi.org/10.2319/092010-547.1 PMid:21306222

2. Beckwith FR, Ackerman RJ, Cobband CM, Tira DE. An evaluation of factors affecting duration of orthodontic treatment. Am J Orthod Dentofacial Orthop. 1999;115:439-47.

PMid: 10194290

3. Verrusio C, lorio-Siciliano V, Blasi A, Leuci S, Adamo D, Nicolo M. The effect of orthodontic treatment on periodontal tissue inflammation: A systematic review. Quintessence Int. 2018;49(1):69-77.

PMid:29114647

4. Wang SY, Yang YH, Chang HP. The effect of an oral hygiene instruction intervention on plaque control by orthodontic patients. J Dent Sci. 2007;2(1):45-51.

5. Martha K, Mezei T, Janos K. A histological analysis of gingival condition associated with orthodontic treatment. Rom J Morphol Embryol. 2013;54(3 Suppl):823-7

PMid:24322034

6. Su Y, Chen C, Guo L, Du J, Li X, Liu Y. Ecological balance of oral microbiota is required to maintain oral mesenchymal stem cell homeostasis. Stem Cell. 2017;36(4):551-61. https://doi. org/10.1002/stem.2762 PMid:29266799

7. Torlakovic L, Paster BJ, Ogaard B, Olsen I. Changes in the supragingival microbiota surrounding brackets of upper central incisors during orthodontic treatment. Acta Odontol Scand. 2013;71(6):1547-54. https://doi.org/10.3109/00016357.2013.77 6107

\section{PMid:24180590}

8. Babacan H, Sokucu O, Marakoglu I, Ozdemir H, Nalcaci R. Effect of fixed appliances on oral malodor. Am J Orthod Dentofacial Orthop. 2011;139(3):351-5. https://doi.org/10.1016/j. ajodo.2009.03.055

9. Liu H, Sun J, Dong $Y$, Lu H, Zhou H, Hansen BF, Song $X$. Periodontal health and relative quantity of subgingival Porphyromonas gingivalis during orthodontic treatment. Angle Orthod. 2011;81:609-15. https://doi.org/10.2319/082310-352.1 PMid:21306224

10. Folco AA, Benı'tez-Roge' SC, Iglesias $M$, Calabrese $D$, Pelizardi C, Rosa A, Brusca MI, et al. Gingival response in orthodontic patients: Comparative study between selfligating and conventional brackets. Acta Odontol Latinoam. 2014;27(3):120-4. PMid:25560690

11. Arneberg P, Ogaard B, Scheie AA, Rølla G. Selection of Streptococcus mutans and lactobacilli in an intra-oral human caries model. J Dent Res. 1984;63(10):1197-2000. https://doi. org/10.1177/00220345840630100501 PMid:6384298

12. Petti S, Barbato E, Simonetti D'Arca A. Effect of orthodontic therapy with fixed and removable appliances on oral microbiota: A six-month longitudinal study. New Microbiol. 1997;20(1):55-62. PMid:9037669

13. Dale BA. Periodontal epithelium: A newly recognized role in health and disease. Periodontol 2000. 2002;30:70-8. https://doi. org/10.1034/j.1600-0757.2002.03007.x PMid:12236897

14. Bosshardt DD, Lang NP. The junctional epithelium: From health to disease. J Dent Res. 2005;84(1):9-20. https://doi. org/10.1177/154405910508400102 PMid:15615869

15. Pejcic A, Kojovic D, Kesic L, Obradovic R. The effects of low level laser irradiation on gingival inflammation. Photomed Laser
Surg. 2010;28(1):69-74. https://doi.org/10.1089/pho.2008.2301 PMid:19929224

16. Zare D, Haerian A, Molla R, Vaziri F. Evaluation of the effects of diode $(980 \mathrm{Nm}$ ) laser on gingival inflammation after nonsurgical periodontal therapy. J Lasers Med Sci. 2014;5(1):28-31. PMid:25606336

17. Goldstep F, Freedman G. Diode lasers for periodontal treatment The story so far. J Oral Health. 2009;45-6.

18. Yilmaz S, Kuru B, Kuru L, Noyan U, Argun D, Kadir T. Effect of gallium arsenide diode laser on human periodontal disease: A microbiological and clinical study. Lasers Surg Med. 2002;30(1):606. https://doi.org/10.1002/lsm.10010 PMid:11857606

19. Gokhale SR, Padhye AM, Byakod G, Jain SA, Padbidri V, Shivaswamy S. A comparative evaluation of the efficacy of diode laser as an adjunct to mechanical debridement versus conventional mechanical debridement in periodontal flap surgery: A clinical and microbiological study. Photomed Laser Surg. 2012;30(10):598-603. https://doi.org/10.1089/ pho.2012.3252 PMid:22889285

20. Güncü GN, Tözüm TF, Cağlayan F. Effects of endogenous sex hormones on the periodontium review of literature. Aust Dent J. 2005;50(3):138-45. https://doi.org/10.1111/j.1834-7819.2005. tb00352.x

PMid: 16238210

21. Claffey N, Egelberg J. Clinical indicators of probing attachment loss following initial periodontal treatment in advanced periodontitis patients. J Clin Periodontal. 1995;22(9):690-6. https://doi.org/10.1111/j.1600-051x.1995.tb00828.x

PMid:7593699

22. Checchi L, Montevecchi M, Checchi V, Zappulla F. The Relationship between bleeding on probing and subgingival deposits. An endoscopical evaluation. Open Dent J. 2009;3:15460. https://doi.org/10.2174/1874210600903010154 PMid:19672332

23. Kurgan Ş, Fentoğlu Ö, Önder C, Serdar M, Eser F, Tatakis DN, et al. The effects of periodontal therapy on gingival crevicular fluid matrix metalloproteinase-8, interleukin- 6 and prostaglandin E2 levels in patients with rheumatoid arthritis. J Periodont Res. 2016;51(5):586-95. https://doi.org/10.1111/jre.12337 PMid:26575440

24. Slots J. Rapid identification of important periodontal microorganisms by cultivation, 1986. Oral Microbiol Immunol. 1986;1(1):48-57. https://doi.org/10.1111/j.1399-302x.1986. tb00318.x PMid:3295680

25. Wilkins TD, Chalgren S. Antimicrobial. Agent Chemother 1976;10:926.

26. Mahon C, Manuselis JR. Diagnostic Microbiology. Philadelphia: WB Saunders Company; 2000. p. 1165.

27. Collee JG, Miles RS, Watt B. Mackie and McCartney Practical Medical Microbiology. $14^{\text {th }}$ ed. New York: Churchill Livingstone; 1996.

28. Feres M, Haffajee AD, Allard K, Socransky SS. Change in subgingival microbial profiles in adult periodontitis subjects. J Clin Periodontol. 2001;28(7):597-609. https://doi. org/10.1034/j.1600-051x.2001.028007597.x

PMid: 11422580

29. Wilson TG Jr., Carnio J, Schenk R, Myers G. Absence of histologic signs of chronic inflammation following closed subgingival scaling and root planing using the dental endoscope: Human biopsies a pilot study. J Periodontol. 2008;79(11):203641. https://doi.org/10.1902/jop.2008.080190 
PMid: 18980510

30. Kreisler M, Christoffers AB, Willershausen B, d'Hoedt B Effect of low-level GaAlAs laser irradiation on the proliferation rate of human periodontal ligament fibroblasts: An in vitro study. J Clin Periodontol. 2003;30(4):353-8. https://doi. org/10.1034/j.1600-051x.2003.00001.x PMid: 12694435

31. Sasaki Y, Hayashi JI, Fujimura T, Nishida YI, Ohno T, Okada K, et al. New irradiation method with indocyanine green-loaded nanospheres for Inactivating periodontal pathogens. Int $\mathrm{J}$ Mol Sci. 2017;18(1):154. https://doi.org/10.3390/ijms18010154

32. Qadri T, Miranda L, Tuner J, Gustafsson A. The short term effects of low-level lasers as adjunct therapy in the treatment of periodontal inflammation. J Clin Periodontol. 2005;32(7):714-9. https://doi.org/10.1111/j.1600-051x.2005.00749.x

PMid:15966876

33. Conlan MJ, Rapley JW, Cobb CM. Biostimulation of wound healing by low-energy laser irradiation. A review. J Clin Periodontol. 1996;23(5):492-6. https://doi.org/10.1111/j.1600051x.1996.tb00580.

\section{PMid:8783057}

34. Goteiner D, Vogel R, Deasy M, Goteiner C. Periodontal and caries experience in children with insulin-dependent diabetes mellitus. J Am Dent Assoc. 1986;113(2):277-9. https://doi. org/10.14219/jada.archive.1986.0166

PMid:3462234

35. Coleton S. Sensitivity and laser treatment. J Am Dent Assoc. 1998;129(9):1200-4.

\section{PMid:9786741}

36. Aykol G, Baser U, Maden I. The effect of low- level laser therapy as an adjunct to non- surgical periodontal treatment. J Periodontol. 2011;82(3):481-8. https://doi.org/10.1902/ jop.2010.100195

PMid:20932157

37. Basford JR. Low-energy laser therapy: Controversies and new research findings. Lasers Surg Med. 1989;9(1):1-5. PMid:2648091

38. Kageyama S, Takeshita T, Asakawa M, Shibata Y, Takeuchi K, Yamanaka W, et al. Relative abundance of total subgingival plaque-specific bacteria in salivary microbiota reflects the overall periodontal condition in patients with periodontitis. PLoS One. 2017;12(4):e0174782. https://doi.org/10.1371/journal. pone.0174782

PMid:28369125

39. Petrović MS, Kannosh IY, Milašin JM, Mihailović DS, Obradović RR, Bubanj SR, et al. Clinical, microbiological and cytomorphometric evaluation of low-level laser therapy as an adjunct to periodontal therapy in patients with chronic periodontitis. Int J Dent Hyg. 2018;16(2):e120-7. https://doi. org/10.1111/idh.12328

PMid:29327449

40. Birang R, Shahaboui M, Kiani S, Shadmehr E, Naghsh N. Effect of nonsurgical periodontal treatment combined with diode laser or photodynamic therapy on chronic periodontitis: A randomized controlled split-mouth clinical trial. J Lasers Med Sci. 2015;6(3):112-9. https://doi.org/10.15171/jlms.2015.04 PMid:26464778

41. Gupta S, Sawhney A, Jain G, Dhar S, Gupta B, et al. An evaluation of diode laser as an adjunct to scaling and root planning in the nonsurgical treatment of chronic periodontitis: A clinico-microbiological study. Dent Med Res. 2016;4(2):44-9. https://doi.org/10.4103/2348-1471.184733

42. Lai SM, Zee KY, Lai MK, Corbet EF. Clinical and radiographic investigation of the adjunctive effects of a low- power $\mathrm{HeNe}$ laser in the treatment of moderate to advanced periodontal disease: A pilot study. Photomed Laser Surg. 2009;27:287-93. https://doi.org/10.1089/pho.2007.2206 PMid: 18785848

43. Angelov N, Pesevska S, Nakova M, Gjorgoski I, Ivanovski K, Angelova D, et al. Periodontal treatment with a low- level diode laser: Clinical findings. Gen Dent. 2009;57(5):510-3. PMid:19903643

44. Pesevska S, Nakova M, Gjorgoski I, Angelov N, Ivanovski K, Nares S, et al. Effect of laser on TNF- alpha expression in inflamed human gingival tissue. Lasers Med Sci. 2012;27(2):377-81. https://doi.org/10.1007/s10103-011-0898-x PMid:21380536

45. Calderın S, Garcıa-Nunez JA, Gomez C. Short term clinical and osteoimmunological effects of scaling and root planing complemented by simple or repeated laser phototherapy in chronic periodontitis. Lasers Med Sci. 2013;28(1):157-66. https://doi.org/10.1007/s10103-012-1104-5 PMid:22546942

46. Makhlouf M, Dahaba MM, Tuner J, Eissa SA, Harhash TA. Effect of adjunctive low level laser therapy (LLLT) on nonsurgical treatment of chronic periodontitis. Photomed Laser Surg. 2012;30(3):160-6. https://doi.org/10.1089/pho.2011.3069 PMid:22233558

47. Ribeiro IW, Sbrana MC, Esper LA, Almeida AL. Evaluation of the effect of the GaAlAs laser on subgingival scaling and root planing. Photomed Laser Surg. 2008;26(4):387-91. https://doi. org/10.1089/pho.2007.2152

PMid:18647095 